\title{
Corporate Governance and Firm Performance: A Case study of Karachi Stock Market
}

\author{
Ghulam Mustafa \\ g.mustafa@ucp.edu.pk \\ Lecturer, School of Accounting and Finance, Faculty of Management Studies, UCP
}

\author{
Abid Rasheed \\ abid.choudhry@gmail.com \\ Lecturer, School of Accounting and Finance, Faculty of \\ Management Studies, UCP
}

\author{
Anum Khalid \\ Mphil Scholar \\ School of Accounting and Finance, Faculty of \\ Management Studies, UCP
}

\begin{abstract}
\section{Introduction}

A sustainable economic development is carried out by the help of good corporate governance, by enhancing their capital and companies progress. In under developing or emerging new markets public policy objectives are severed by the good corporate objectives. Reduces vulnerability of the financial crises, reinforcement property rights; reduces transaction cost and cost of capital and leads to capital market development. In Pakistan, the publication of the SECP Corporate Governance Code 2002 for publicly listed companies has made it an important area of research of corporate sector.

The governance is a system which is made up with the wide range of practices and institutions, from accounting standards and law concerning disclosure about finance. It also defines a person who owns a firm, and dictates the rules by which economic returns are distributed among shareholders, employees, managers, and other stakeholders. As such, a country's corporate governance regime has deep implications for firm organization, employment systems, trading relationships, and capital markets. Thus, changes in Pakistani system of corporate governance are likely to have important consequences for the structure and conduct of country business.

The code of corporate governance introduced by SECP in early 2002 is the major step in corporate governance reforms in Pakistan. The code includes many recommendations in line with international good practice. The major areas of enforcement
\end{abstract}

This paper seeks to study the relationship between corporate governance and firm's performance of twenty five companies listed at Karachi Stock Market. The performance of corporate governance is analyzed through whereas the performance of the companies is measured by return on assets (ROA) and return on equity (ROE). The data set is obtained from the State Bank of Pakistan Annual Reports for the year 2011-2015. The multiple regression models are applied to check the significance of corporate governance and firm profit. The result shows that leverage and growth have a positive relationship between impacts in measure performance of the firm.

Keywords: Corporate Governance, Firm Performance, Return of asset, Return of equity, Karachi Stock Market

include reforms of board of directors in order to make it accountable to all shareholders and better disclosure including improved internal and external audits for listed companies. However, the code's limited provisions on director's independence remain voluntary and provide no guidance on internal controls, risk management and board compensation policies.

The main focus of this study is to examine the relationship between corporate governance and firm performance for publicly listed Karachi Stock Exchange (KSE) firms. Therefore, we attempt to identify the relationship between corporate governance proxies and firm value in our sample of KSE firms.

\section{Problem statement}

There should be best performance of all sectors of Karachi Stock Exchange but there is not such good performances by Karachi sectors. However Karachi sectors have not good performance so there is need to conduct a research on it to locate an out effect of corporate governance on firm performance.

\section{Research Question}

What is the effect of corporate governance with overall performance of firm?

Hypotheses

$\mathrm{H} 1_{\mathrm{a}}=$ there is no significance relationship between firms size, leverage and firm growth with corporate governance

$\mathrm{H} 1_{\mathrm{b}}=$ there is significant relationship between firms size, leverage and firm growth with corporate governance.

The current issue and full text archive of this journal is available at www.jraspublications.org/index.php/JRAS/issue/archive Journal of Research in Administrative Sciences (JRAS) VIII(II), 6-9, ISSN: 2664-2433 


\section{Literature Review}

Evidence from previous empirical study from educational literature has sought to confirm the effect of corporate governance on a firm's performance. There is aoutsized body of empirical research that has assessed the impact of corporate governance on firm performance for the developed markets. Research have shown that good governance practices have led the significant increase in the economic value added of firms, higher productivity and lower risk of systematic financial failure for countries.

(Mitto, 2001)Suggestedthat better price performance is associated with firms that have indicators of higher disclosure quality, with firms that have higher outside ownership concentration and with firms that are focused rather than diversified.

(Brown, 2004)found indicate that better governed firms are relatively more profitable, more valuable and pay more cash to their shareholders. (Gompers, 2003) concluded that firms with fewer shareholder rights have lower firm valuations and lower stock returns and firms with stronger shareholders rights have higher firm value, higher profits, higher sales growth, lowest capital expenditures, and made fewer corporate acquisitions (Lipton, 1992)concluded that It is expected that limiting board size is to improve firm performance because the benefits by larger boards of increased monitoring are outweighed by the poorer communication and decision-making of larger groups.

The relation between the proportion of outside directors, a proxy for board independence, and firm performance is inconclusive. (Fosberg, 1989)(Bhagat, 2002)find no linkage between proportion of outsider directors and return on assets, asset turnover and stock returns.

The evidence on the association between audit-related governance factors and firm performance is mixed. Brown and Caylor (2004) show that independence,(Klein, 2002)documents a negative relation between earnings management and audit committee independence, and (Anderson, 2004)find that entirely independent audit committees have lower debt financing costs. (Frankel, 2002)show a negative relation between earnings management and auditor independence (based on audit versus non-audit fees). However, (Agrawal)and (Larcker, 2004)come up with a contradictory evidence. Kinney, et al. (2004) findings show no association between earnings restatements and fees paid for financial information systems design and implementation or internal audit services, and (Agrawal, Corporate Governance and Accounting Scandals., 2005)up with similar conclusion in this regard. (Yermack, 1996))found the separation of CEO and chairman affects firms' performance because the agency problems are higher when the same person holds both positions.

In the past few years, corporate governance has become an important area of research in Pakistan. In his noteworthy work (Cheema, 2003)suggests that corporate governance can play a significant role for Pakistan to attract foreign direct investment and mobilise greater saving through capital provided the corporate governance system is compatible with the objective of raising external equity capital through capital markets.

Rais and Saeed (2005) analyze the Corporate Governance Code 2002 in the light of Regulatory Impact Assessment (RIA) framework and its enforcement and application in Pakistan in order to understand the dynamics of public decision making and assess the efficacy of the regulation policy of SECP in the arena of corporate governance. The analysis shows that though the listed companies are gearing themselves up to adopt the Code, there are some constraints, and reservations about the way it was drafted and implemented.

\section{Conceptual Framework}

In this study the conceptualization is known as framework of key concepts. Its shows the relationship between dependent variable and independent variables. Here the independent variables are size, leverage and growth. Two variables are dependent which are Return of Asset (ROA) and Return of Equity (ROE).

Figure \# 1

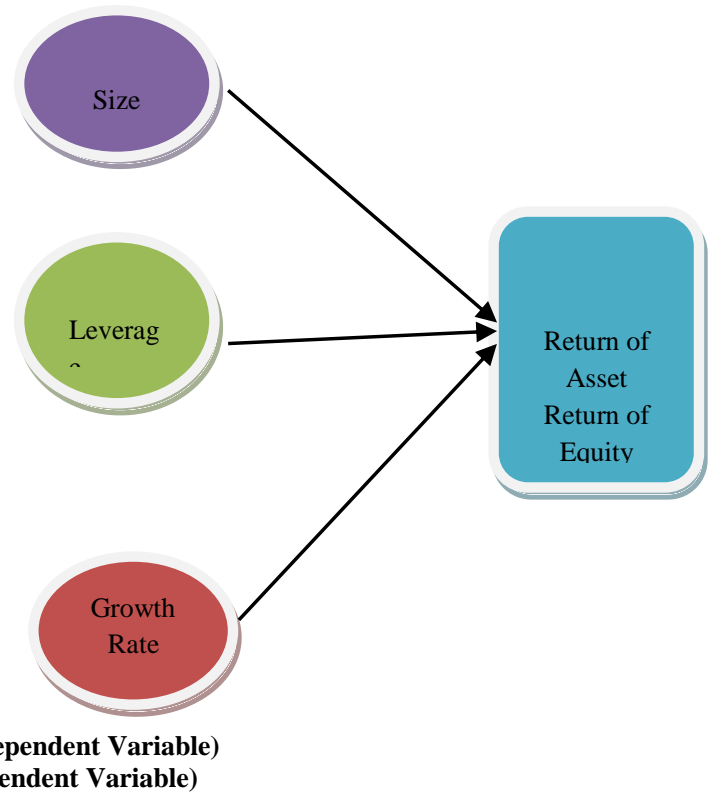

(Dependent Variable)

\section{Methodology}

For this research I have been taken secondary data of both sectors of Karachi stock exchange twenty five companies are selected .The data has been taken from State Bank of Pakistan I complied previous studies 5-years data of these sectors from (20112015).For this research our dependent variables are Return of Asset and return of equity and Independent variables are Size, leverage and Growth. I have used to SPSS to check the significance of the data after we apply multiple regression model for the data.

\section{Model specification}

The data of the study takes from five years periods it has sample of 25 firms which are in Karachi Stock Exchange. Data collected from the annual report of all selected firms. For the estimation of result regression analysis applied on pooled sample equation. $\mathrm{Y}_{\mathrm{it}}=\beta_{\mathrm{o}}+\beta_{1} \mathrm{X} 1_{\mathrm{it}}+\beta_{2} \mathrm{X} 2_{\mathrm{it}}+\beta_{3} \mathrm{X} 3_{\mathrm{it}}+\mathrm{u}_{\mathrm{it}}$ Where,

$\mathrm{Y}_{\text {it }}$ represents Return on Asset (ROA) and Return on Equity (ROE) for firm $i$ and time t.

* $\quad \mathrm{X}_{\text {it }}$ represents firm's size (size) for firm i and time t.

* $\mathrm{X} 2_{\text {it }}$ represents LEVERAGE for firm i at time $\mathrm{t}$.

- X3it represents ratio of GROWTH for firm I at time t.

* i= 1 to25 firms

* $\mathrm{t}=2011-2015$

* u=Error term.

Pooling is that reliable and satisfies method of to obtain result from model. The relationship between corporate governance and firm profitability is stable /equal across the firm there for pooled procedure best for this type of data 


\section{Result and Analysis \\ Return of Asset}

a. Predictors: (Constant), Growth rate=Present Sale- Previous Sale/ Previous Sale * 100 , L=T. Liabilities / T.Asset, log of total assets b. Dependent Variable: Return of Equity

\begin{tabular}{ccccccccccc} 
Model & $\mathrm{R}$ & $\mathrm{R}$ Square & \multicolumn{1}{c}{ S̆quare } & the Estimate & Change & F Change & df1 & df2 & Statistics & Watson \\
\hline 1 & $.291^{\mathrm{a}}$ & .084 & .062 & 91.83885 & .084 & 3.687 & 3 & 120 & .014 & 1.787 \\
\hline
\end{tabular}

In this table show the $\mathrm{R}^{2}$ value should lie between 0 and 1 .The researcher is interested in the high value of $\mathrm{R}^{2} \cdot$ In this particular the value of $\mathrm{R} 2$ is .084 shows that $84 \%$ variation in the return on Equity is explained by the size, leverage and growth. $\mathrm{R}$ shows the

degree of association between ROE with size, leverage and growth. The value is .291 which shows moderate degree of association between the variables.

ANOVA

\begin{tabular}{llrrrrr}
\hline Model & & Sum of Squares & df & Mean Square & F & Sig. \\
\hline 1 & Regression & 2634.434 & 3 & 878.145 & 3.591 & $.016^{\mathrm{a}}$ \\
& Residual & 29342.617 & 120 & 244.522 & &
\end{tabular}

a. Predictors: (Constant), Growth rate=Present Sale- Previous Sale/ Previous Sale * 100, L=T. Liabilities / T.Asset, log of total assets

b. Dependent Variable: Return of Asset

In this table shows the value of F-Statistics is 3.591 with P-Value .016 which is less than 0.05 shows that model is significant and is a good fit.

Coefficient

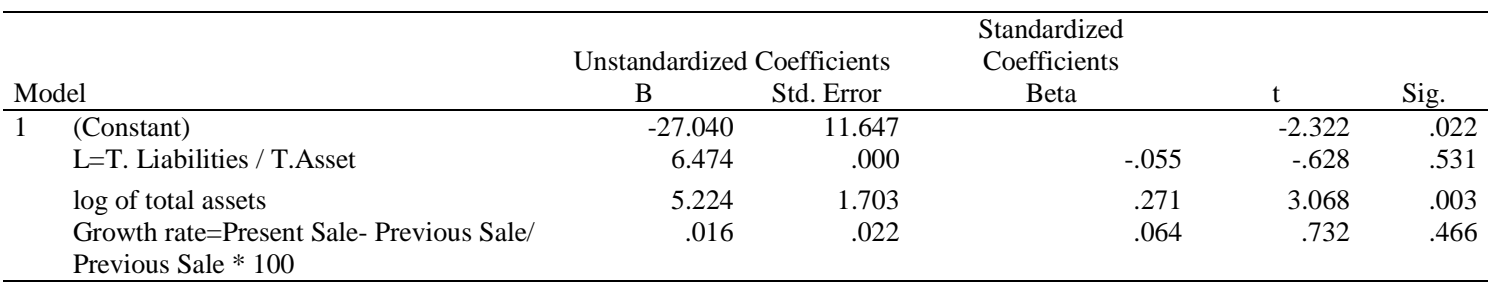

In this table shows the $\beta 1$ is the regression coefficient of leverage and tells us that with the influence of size and growth rate held constant, the return of asset increase the 6.474 .

Model Summary ${ }^{\mathrm{b}}$

\section{Return of Equity}

\begin{tabular}{|c|c|c|c|c|c|c|c|c|c|c|}
\hline \multirow[b]{2}{*}{ Model } & \multirow[b]{2}{*}{$\mathrm{R}$} & \multirow[b]{2}{*}{ R Square } & \multirow[b]{2}{*}{$\begin{array}{l}\text { Adjusted R } \\
\text { Square }\end{array}$} & \multirow[b]{2}{*}{$\begin{array}{l}\text { Std. Error of } \\
\text { the Estimate }\end{array}$} & \multicolumn{4}{|c|}{ Change Statistics } & \multirow[b]{2}{*}{$\begin{array}{c}\text { Sig. F } \\
\text { Change }\end{array}$} & \multirow[b]{2}{*}{$\begin{array}{l}\text { Durbin- } \\
\text { Watson }\end{array}$} \\
\hline & & & & & $\begin{array}{l}\text { R Square } \\
\text { Change }\end{array}$ & F Change & df1 & df2 & & \\
\hline 1 & $.287^{\mathrm{a}}$ & .082 & .059 & 15.63719 & .082 & 3.591 & 3 & 120 & .016 & .676 \\
\hline
\end{tabular}

a. Predictors: (Constant), Growth rate=Present Sale- Previous Sale/ Previous Sale * 100 , L=T. Liabilities / T.Asset, log of total assets

b. Dependent Variable: Return of Asset.

In this table show the $\mathrm{R}^{2}$ value should lie between 0 and 1 .The researcher is interested in the high value of $\mathrm{R}^{2}$.In this particular the value of $\mathrm{R} 2$ is .082 shows that $82 \%$ variation in the return on equity is explained by the size, leverage and growth. R shows the degree of association between ROE with size, leverage and growth. The value is .287 which shows moderate degree of association between the variables.

\begin{tabular}{llrrrr}
\multicolumn{3}{c}{ ANOVA $^{\mathbf{b}}$} & \multicolumn{1}{c}{ df } & Mean Square & F \\
\hline Model & & Sum of Squares & 3 & 878.145 & 3.591 \\
& Regression & 2634.434 & 120 & 244.522
\end{tabular}

a. Predictors: (Constant), Growth rate=Present Sale- Previous Sale/ Previous Sale * 100 , L=T. Liabilities / T.Asset, log of total assets b. Dependent Variable: Return of Asset

In this table show the value of F-Statistics is 3.591 with P-Value .016 which is less than 0.05 shows that model is significant and is a good fit.

Coefficient

\begin{tabular}{|c|c|c|c|c|c|c|}
\hline \multirow{2}{*}{\multicolumn{2}{|c|}{ Model }} & \multicolumn{2}{|c|}{ Unstandardized Coefficients } & \multicolumn{3}{|l|}{$\begin{array}{l}\text { Standardized } \\
\text { Coefficients }\end{array}$} \\
\hline & & B & Std. Error & Beta & $\mathrm{t}$ & Sig. \\
\hline 1 & (Constant) & -27.040 & 11.647 & & -2.322 & .022 \\
\hline & $\mathrm{L}=\mathrm{T}$. Liabilities / T.Asset & 6.474 & .000 & -.055 & -.628 & .531 \\
\hline & $\log$ of total assets & 5.224 & 1.703 & .271 & 3.068 & .003 \\
\hline & $\begin{array}{l}\text { Growth }=\text { Present Sale- Previous } \\
\text { Sale/ Previous Sale } * 100\end{array}$ & .016 & .022 & .064 & .732 & .466 \\
\hline
\end{tabular}

In this table shows the $\beta 1$ is the regression coefficient of leverage and tells us that with the influence of size and growth held constant, the return of asset increase the 6.474 . 


\section{Conclusion:}

This research has been conducted to find out the relationship between corporate governance and firm performance of twenty five listed at Karachi Stock Exchange. Data was take of 25 companies listed in Karachi Stock exchange.ROA and ROE two profitability ratios are use to find out the corporate governance with firms performance. After applying regression model on data of all companies listed in Karachi stock exchange the result show that there is positive relationship between corporate governance and firm performance.

\section{Reference}

i. Agrawal, A. a. (2005). Corporate Governance and Accounting Scandals. Journal of Law and Economics .

ii. Agrawal, A. a. (n.d.). Corporate Governance and Accounting scandles. Journal of Law and Economics , 39.

iii. Anderson, R. S. (2004). The Cost of Debt. Journal of Accounting and Economics , 315-342.

iv. Bhagat, S. a. (2002). Non-correlation Between Board Independence and Long-term Firm Performance. Journal of Corporation Law , 231-274. v. Brown, L. D. (2004). Corporate Governance and Firm performance.

vi. Cheema, A. (2003). Corporate Governance in Pakistan: Issues and Concerns .

vii. Fosberg, R. (1989). Outside Directors and Managerial Monitoring. Akron Business and Economic Review , 24-32.

viii. Frankel, R. M. (2002). The Relation Between Auditors' Fees for Non-audit Services and Earnings Management.

ix. Gompers, P. L. (2003). Corporate Governance and Equity Prices. Quarterly Journal of Economics, , 107-55.

x. x. Klein, A. (2002). Audit Committee, Board of Director Characteristics, and Earnings Management. Journal of Accounting and Economics , 375-400.

xi. Larcker, D. S. (2004). How Important is Corporate Governance.

xii. Lipton, M. a. (1992, November). A Modest Proposal for Improved Corporate Overnance. 59-77.

xiii. xiii. Mitto, T. (2001). Acrossfirmaalysisof. jouraloffiaacial, $50(5)$.

xiv. Yermack, D. (1996)). Higher Market Valuation for Firms With a Small Board of Directors. Journal of Financial Economics , 185-211. 